\title{
RNA/DNA ratios as indicators of metabolic activity in four species of Caribbean reef-building corals
}

\author{
Bradley A. Buckley ${ }^{1,2, *}$, Alina M. Szmant ${ }^{1,3}$ \\ ${ }^{1}$ Rosenstiel School of Marine and Atmospheric Sciences, University of Miami, 4600 Rickenbacker Causeway, \\ Virginia Key, Florida 33149, USA \\ ${ }^{2}$ Hopkins Marine Station, Stanford University, 120 Oceanview Boulevard, Pacific Grove, California 93950, USA \\ ${ }^{3}$ Center for Marine Science, University of North Carolina at Wilmington, 5600 Marvin K. Moss Lane, Wilmington, \\ North Carolina 28409, USA
}

\begin{abstract}
Global climate change and the anthropogenic degradation of tropical reef environments can have deleterious consequences for the health of reef-building corals. Bioindicators of coral status aid in efforts to identify those species and populations that are most threatened, which can help focus conservation efforts. The RNA/DNA ratio is an index of protein synthetic capacity and is expected to reflect an organism's investment in growth. Here, we measured a decrease in the RNA/DNA ratio in both the symbiotic anemone Aiptasia pallida exposed to light-deprivation in the laboratory, and in natural populations of the coral Porites astreoides along a depth gradient, suggesting that the RNA/DNA ratio may have depended upon metabolic activity. Also, RNA/DNA ratios in the coral Montastraea annularis were higher in the winter and spring (when higher growth rates may have been supported) than in summer, at an inshore and an offshore reef in the Florida Keys. Site-specific disparity in bleaching patterns at these 2 reefs may partly explain the differences in their RNA/DNA ratios. Finally, significant interspecific variation was observed in 3 co-occurring species of the genus Montastraea: $M$. annularis, $M$. cavernosa and $M$. faveolata, demonstrating the potential for variability in protein synthetic capacity even between closely related species. These results support the use of the RNA/DNA ratio as an indicator of metabolic activity in natural populations of corals.
\end{abstract}

KEY WORDS: RNA/DNA ratios $\cdot$ Bioindicator $\cdot$ Corals

\section{INTRODUCTION}

Climate change impacts the health of reef-building corals both globally, in the form of widespread bleaching due to rising seawater temperatures (Glynn 1993, Hoegh-Guldberg 1999, Hughes et al. 2003), as well as locally, as parameters including temperature stress, UV exposure and storm damage can vary on small spatial scales (Wilkinson 1996, Gardner et al. 2003, Helmuth et al. 2002). Other factors such as turbidity, sedimentation and overfishing can also have localized impacts on reef health (Wilkinson 1996, Brown 1997, Hughes et al. 2003). Therefore, to aid in conservation efforts, accurate metrics of coral status are desired to determine those species and populations most threat- ened by a regional set of environmental stressors. Numerous biochemical indices have been examined in corals, including the induction of heat shock proteins (Black et al. 1995, Hayes \& King 1995, Downs et al. 2002), the regulation of antioxidant enzymes (Shick et al. 1995, Downs et al. 2002) and the accumulation of ubiquitin-conjugated proteins (Downs et al. 2000). The positive correlation between variation in these indices and the intensity of various stressors has led to the promotion of a molecular biomarker system for assaying coral health (Downs et al. 2000).

Another potentially informative indicator of metabolic state is the RNA/DNA ratio, an index already broadly employed to determine protein synthetic capacity and growth rate in fishes (Buckley 1984, Bulow 
1987, Malloy \& Targett 1994, Buckley et al. 1999, McNamara et al. 1999, Gwak et al. 2003) and in marine invertebrates (Wright \& Hetzel 1985, Frantzis et al. 1992, Dahlhoff \& Menge 1996, Chícaro et al. 2001, Dahlhoff et al. 2001) including corals (Bak \& Meesters 2002, Meesters et al. 2002). The usefulness of this ratio is dependent upon the fact that the amount of DNA per cell is fixed, while that of RNA varies with metabolic demand. Therefore, during periods of active protein production, such as those associated with growth or differentiation, the RNA/DNA ratio is predicted to be higher than during periods when protein metabolism is low. Similarly, at sites that promote coral growth, such as those where photosynthetically available radiation (PAR) is high enough to support robust zooxanthellate photosynthesis and translocation of photosynthate, the ratio should be higher than at sites that support lower growth rates or metabolic activity, e.g. at greater depth. This prediction is consistent with the findings of Meesters et al. (2002), who measured depthdependent decreases in the RNA/DNA ratio in species of the genus Porites. Among the remaining questions concerning the RNA/DNA ratio in reef corals are: (1) does the ratio respond directly to starvation in the laboratory, an important consideration for inferring metabolic activity in the field, (2) how does the ratio vary with season and (3) between closely located sites that differ environmentally, and (4) to what extent does the ratio vary among co-occurring congeners?

(1) Here, we tested whether the ratio was affected by light limitation (PAR availability) in a symbiotic cnidarian, the anemone Aiptasia pallida, exposed to darkness in the laboratory. (2) In field studies conducted in the Florida Key reef tract in 1998 and 1999, RNA/DNA ratios were measured in the coral Porites astreoides collected along a depth gradient. (3) Seasonal variation in the RNA/DNA ratio was recorded in the coral Montastraea annularis, collected at 2 sites that differ in depth, proximity to shore and turbidity, and which displayed different temporal patterns of bleaching during the sampling period. (4) To assess intra-genus differences in the RNA/DNA ratio at a single site, ratios were measured in co-occurring individuals of $M$. annularis, M. cavernosa and M. faveolata sampled simultaneously. Taken together, the results increase our understanding of how different environmental factors impact RNA/DNA ratios in natural populations of reef-building corals.

\section{MATERIALS AND METHODS}

Collection of corals. All corals used for these experiments are common Caribbean reef-builders and were collected in the Florida Keys reef tract by SCUBA divers. For the depth study, 5 to $10 \mathrm{~cm}^{2}$ chips of Porites astreoides were collected at an unnamed reef south of Molasses Reef. Chips were removed with hammer and chisel; samples were taken from the apices of colonies in all cases. At the surface, they were wrapped in aluminum foil and frozen in liquid nitrogen. We sampled 10 colonies each at 3,10 and $20 \mathrm{~m}$. Ambient light levels at each depth were recorded with a LICOR light meter. Coral chips were transported to the laboratory and held at $-80^{\circ} \mathrm{C}$ until analyzed to determine their RNA/DNA ratio. For the seasonal study, 5 to $10 \mathrm{~cm}^{2}$ chips of Montastraea annularis were collected as outlined above from 2 sites: Little Grecian reef (LG) $\left(25^{\circ} 07^{\prime} \mathrm{N}, 80^{\circ} 18^{\prime} \mathrm{W}\right)$ at a depth of $9 \mathrm{~m}$ and The Rocks (TR) $\left(24^{\circ} 57^{\prime} \mathrm{N}\right.$, $80^{\circ} 33^{\prime} \mathrm{W}$ ), at a depth of $3 \mathrm{~m}$. LG is an offshore reef located $4.2 \mathrm{n}$ miles off Key Largo, while TR is an inshore reef, situated $0.7 \mathrm{n}$ miles from the coast. We sampled 5 colonies at each time point. Sampling dates were June, July, August, September and November of 1998, and February and April of 1999. The lack of equal temporal spacing between collection dates is due to the fact that collections were conducted as part of an extensive, cooperative sampling regime with other parties that included more frequent collections in the summer months than in subsequent seasons, and weather was often bad. Therefore sampling was not conducted according to a strictly monthly pattern. Sampling was always conducted between 11:00 and 14:00 $\mathrm{h}$ to reduce the confounding effects of diel variation in the RNA/DNA ratios (diel variability has been measured in oysters: Chícaro et al. 2001).

Additional sampling was conducted in September 1998 at LG, to test the interspecific variation in the RNA/DNA ratio at a single site. We sampled 5 colonies of 3 abundant Montastraea species ( $M$. annularis, M. cavernosa and M. faveolata) at a depth of $9 \mathrm{~m}$; these were handled as described above.

Light deprivation in anemones. To establish whether or not the RNA/DNA ratio would respond to shortterm changes in the starvation state of a symbiotic cnidarian, initial tests of this technique were conducted with the anemone Aiptasia pallida. Anemones were collected from seawater outflow pipes at the Rosenstiel School of the University of Miami and kept in aquaria with flow-through seawater at ambient temperatures for $21 \mathrm{~d}$ prior to the experiment, under a $12 \mathrm{~h}$ light/12 h dark cycle. After this period, 10 anemones were transferred to a tank that was kept dark $24 \mathrm{~h}$ per day, while 10 control anemones were maintained under the $12 \mathrm{~h}$ light/12 h dark cycle. After $14 \mathrm{~d}$ all anemones were flash-frozen in liquid nitrogen. Frozen anemones were thawed in 1:4 w/v $2 \mathrm{M} \mathrm{NaCl}$ and homogenized in ground-glass tissue homogenizers for $3 \mathrm{~min}$. Homogenates were spun at $850 \times g$ for $5 \mathrm{~min}$ to 
pellet-out the zooxanthellae; the pellets were discarded and the animal supernatants saved. The RNA/ DNA ratios of the supernatants were measured immediately using the protocol outlined below.

RNA/DNA ratio. Tissue was removed from the coral skeleton with a jet of ice-cold $2 \mathrm{M} \mathrm{NaCl}$ from an artist's airbrush. The tissue slurries were then homogenized for 1 min with an electric mixer (Faberware). Homogenates were centrifuged at $850 \times g$ for 5 min at $4{ }^{\circ} \mathrm{C}$ to pellet-out the zooxanthellae. The animal supernatant was retained and, because of the lability of RNA, the samples were assayed immediately. The RNA/DNA assay is a modified version of the sequential enzymatic digestion protocol developed by Bentle et al. (1981). We mixed $50 \mu \mathrm{l}$ of each crude homogenate with $1.5 \mathrm{ml}$ of $0.005 \mathrm{mg} \mathrm{ml}^{-1}$ ethidium bromide (2,7 diamino-10, ethyl-9, phenylphenanthridium bromide) and $0.1 \mathrm{mg} \mathrm{ml}^{-1}$ Proteinase $\mathrm{K}$, and incubated this at $37^{\circ} \mathrm{C}$ for $90 \mathrm{~min}$. We then added $0.5 \mathrm{ml}$ of buffer (80 mM Tris-Cl, $4 \mathrm{mM} \mathrm{MgCl}_{2}, 3.2 \mathrm{mM} \mathrm{CaCl} \mathrm{C}_{2}$, $\mathrm{pH} 7.7$ at $25^{\circ} \mathrm{C}$ ) to each sample. Fluorescence was measured on a spectrofluorometer (Perkin-Elmer) at an excitation wavelength of $365 \mathrm{~nm}$ and an emission wavelength of $592 \mathrm{~nm}$. Each sample was then incubated with $50 \mu \mathrm{l}$ of RNAse at $37^{\circ} \mathrm{C}$ for $45 \mathrm{~min}$. Fluorescence was measured again to determine the decrease in fluorescence from the initial reading arising from the loss of RNA in the sample. Each sample was then incubated with $50 \mu \mathrm{l}$ of DNAse at $37^{\circ} \mathrm{C}$ for $45 \mathrm{~min}$ and a final reading was taken, with the decrease in fluorescence this time being due to the degradation of DNA in the sample. Fluorescence yield was converted to $\mu \mathrm{g}$ of nucleic acid by comparison with standard curves of 1 to $4 \mu \mathrm{g}$ of DNA from calf thymus (Sigma) and 2 to $8 \mu \mathrm{g}$ of RNA from calf liver (Sigma).

Compounds in coral tissue may absorb light at many wavelengths, including 365 and $592 \mathrm{~nm}$. As a consequence, some of the fluorescence yield in our samples was quenched, resulting in fluorescence values lower than those of $\mathrm{NaCl}$ blanks that contained no nucleic acid. To test whether the quenching was proportional at all concentrations of nucleic acid, standard curves of 1 to $4 \mu \mathrm{g}$ of DNA (Sigma) and 2 to $8 \mu \mathrm{g}$ RNA (Sigma) were prepared in both deionized water and in homogenized coral tissue, and their fluorescence measured. This was conducted for each species used in the study. For all species, the quenching effects of coral tissue were similar at all concentrations of nucleic acid (the results for Montastraea annularis are reported in Fig. 1). The slopes of the DNA standard curves were 31.35 fluorescence units $\mu^{-1}$ DNA in water and 30.13 units ${\mu \mathrm{g}^{-1}}^{-1}$ DNA in homogenized coral tissue. The slopes of the RNA standard curves were 7.76 units ${\mu g^{-1}}^{-1}$ RNA in water and 7.205 units ${\mu g^{-1}}^{-1}$ RNA in coral tissue. As it is the slope of the standard curve that is used to

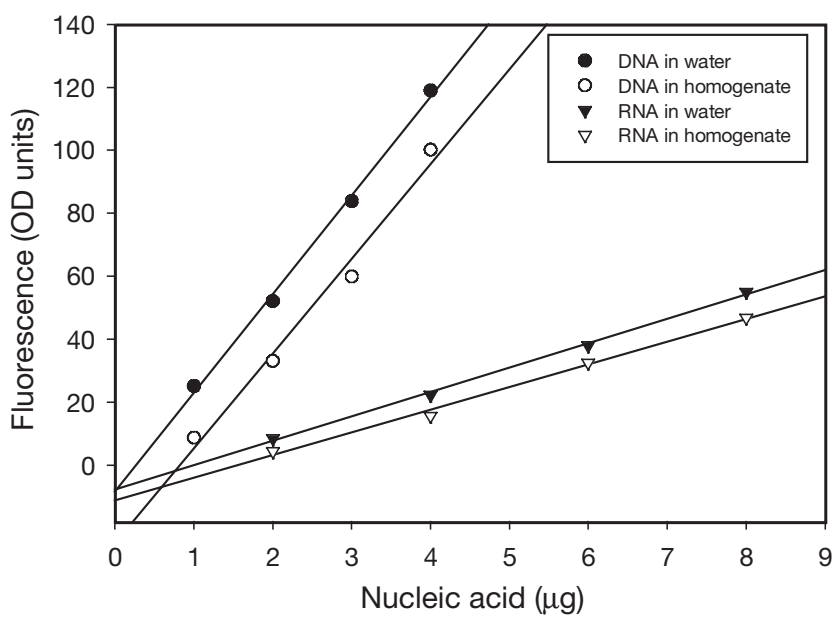

Fig. 1. Standard fluorescence curves of DNA (calf thymus) and RNA (calf liver) prepared in either homogenized coral tissue (Montastraea annularis) or deionized water

generate the RNA/DNA values for the samples, the shift of the $y$-intercept has no effect on the ratio. However, it is recommended that in future applications of this technique to other species of corals, similar trials always be conducted to control for the possibility of uneven quenching effects.

Statistical analyses. The effect of the light regime on the RNA/DNA ratios of Aiptasia pallida was analyzed by Student's $t$-test at $\mathrm{p}<0.05$. In the depth study, a single factor ANOVA tested the effect of depth on the ratio in Porites astreoides; post-hoc pairwise-analysis (Tukey's HSD-test) identified collection depths that differed at $p<0.05$. Linear regression was used to test the correlation between RNA/DNA ratio and percentage of surface radiation. In the seasonal study, for each site independently, a single-factor ANOVA was used to test the effect of collection date, and post-hoc multiple comparison analysis (Tukey test) was conducted to identify sampling time points (within a site only) that differed at $p<0.05$. A single-factor ANOVA was used to test the effect of species on the RNA/DNA ratio in the interspecific study, and a post hoc multiple comparison (Tukey test) was used to determine those species what differed from each other $(p<0.05)$. All analyses were completed with Systat ${ }^{\circledR}$ software.

\section{RESULTS}

\section{Light deprivation in Aiptasia pallida}

In a pilot study designed to determine whether the RNA/DNA ratio would respond to light deprivation, ratios were significantly lower $(t$-test, $p<0.001)$ in 
light-deprived anemones than in anemones exposed to a $12 \mathrm{~h}$ light/12 h dark cycle (Fig. 2). After $14 \mathrm{~d}$ under light-dark cycling, mean RNA/DNA ratios in anemones were approximately $1.5 \times$ higher than in anemones maintained under constant darkness for the $2 \mathrm{wk}$ period.

\section{Depth-related variation in RNA/DNA ratios}

In Porites astreoides, the RNA/DNA ratio decreased as a function of collection depth; the differences were small but significant (ANOVA, p < 0.001, Fig. 3A). The ratio was higher at $3 \mathrm{~m}$, where ambient light levels were also highest, than at either $10 \mathrm{~m}(\mathrm{p}=0.022)$ or $20 \mathrm{~m}(\mathrm{p}=0.007)$. The ratios at the 2 lower depths did not differ significantly from each other $(\mathrm{p}=0.564)$. The irradiances at 3, 10 and $20 \mathrm{~m}$ were 783,464 , and $300 \mu \mathrm{E}$ $\mathrm{m}^{-2} \mathrm{~s}^{-1}$, respectively. RNA/DNA ratios were positively correlated with percentage of radiation at $3 \mathrm{~m}$, and $29 \%$ of the variation in the ratio could be explained by light level (Fig. 3B).

\section{Seasonal variation in RNA/DNA ratios}

RNA/DNA ratios of Montastraea annularis (Fig. 4) varied significantly among collection dates at both LG and TR ( $p<0.0001$ in each case, ANOVA). RNA/DNA ratios at both sites were lowest in early June 1998 (2.6 $\mu \mathrm{g}$ RNA $\mu \mathrm{g}^{-1}$ DNA at both sites), and then rose by $\sim 25 \%$ in July 1998. The mean RNA/DNA ratio continued to rise at TR (Fig. 4B) throughout the summer and autumn, reaching 3.9 in September and 3.4 in Novem-

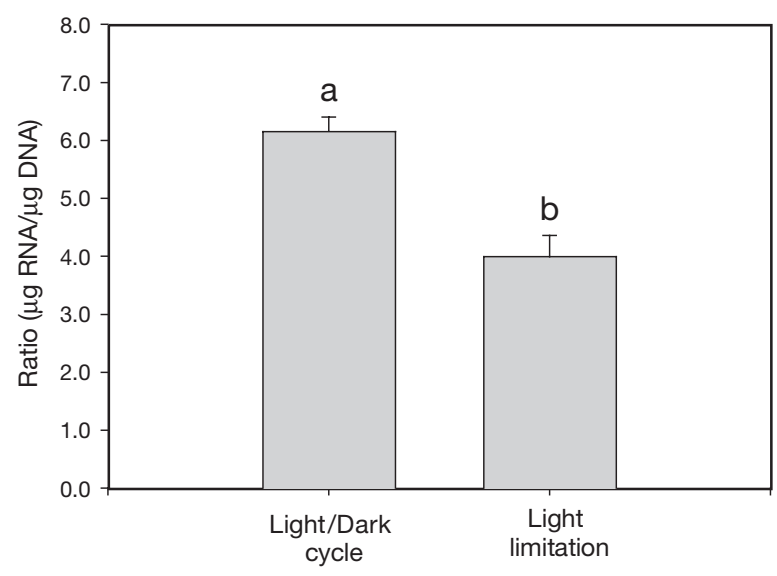

Fig. 2. Aiptasia pallida. RNA/DNA ratios (mean + SEM) for anemones exposed to either a $12 \mathrm{~h} / 12 \mathrm{~h}$ light/dark cycle or to darkness for $14 \mathrm{~d}$. Treatments labeled with different letters varied significantly between each other $(p<0.001)$

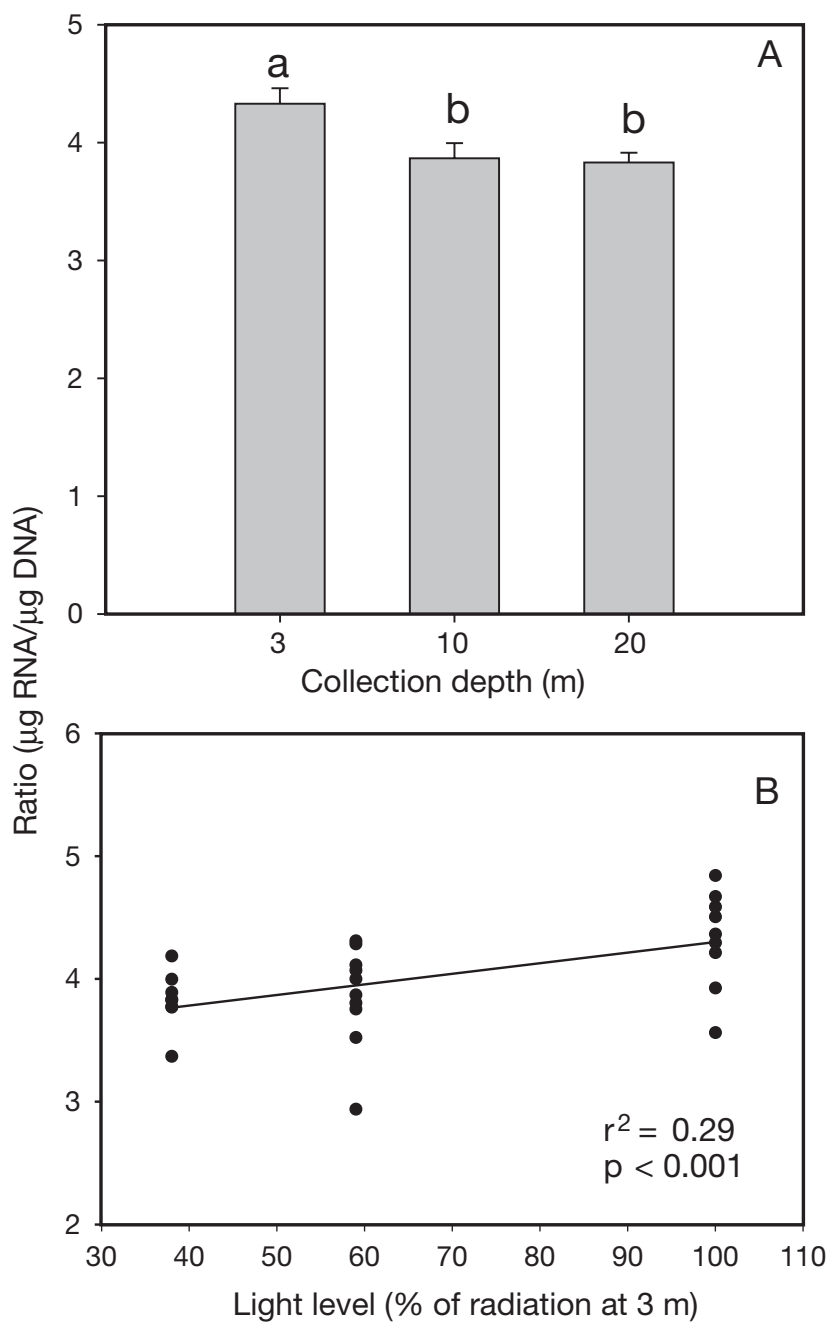

Fig. 3. Porites astreiodes. (A) RNA/DNA ratios (mean $+\mathrm{SE}$; $\mathrm{n}=10$ ) for corals collected at 3,10 or $20 \mathrm{~m}$; depths labeled with different letters varied significantly from each other ( $p<0.05$; post hoc Tukey test; ANOVA for effect of depth, $p<0.001$ ). (B) Linear regression of RNA/DNA ratio versus percentage of light levels $\left(\mu \mathrm{E} \mathrm{m} \mathrm{m}^{-2} \mathrm{~s}^{-1}\right)$ at $3 \mathrm{~m}$

ber 1998. Mean ratios at TR varied little throughout the winter, and peaked at 4.1 in April 1999. At this site, only the ratios in June 1998 were significantly lower than the ratios on the other dates ( $p<0.05$, Tukey test). At LG (Fig. 4A), the mean RNA/DNA ratio dropped from 3.2 in August 1998 to 2.7 in September 1998, coinciding with an acute bleaching event at that site (B.A.B. unpubl. obs.). The RNA/DNA ratio at LG rose gradually through the fall and winter (2.9 in November 1998 and 3.2 in February 1998) and peaked in April 1999 at 3.8. At LG, the summer and autumn ratios (June through November 1998) were all significantly lower than the April 1999 ratios. 


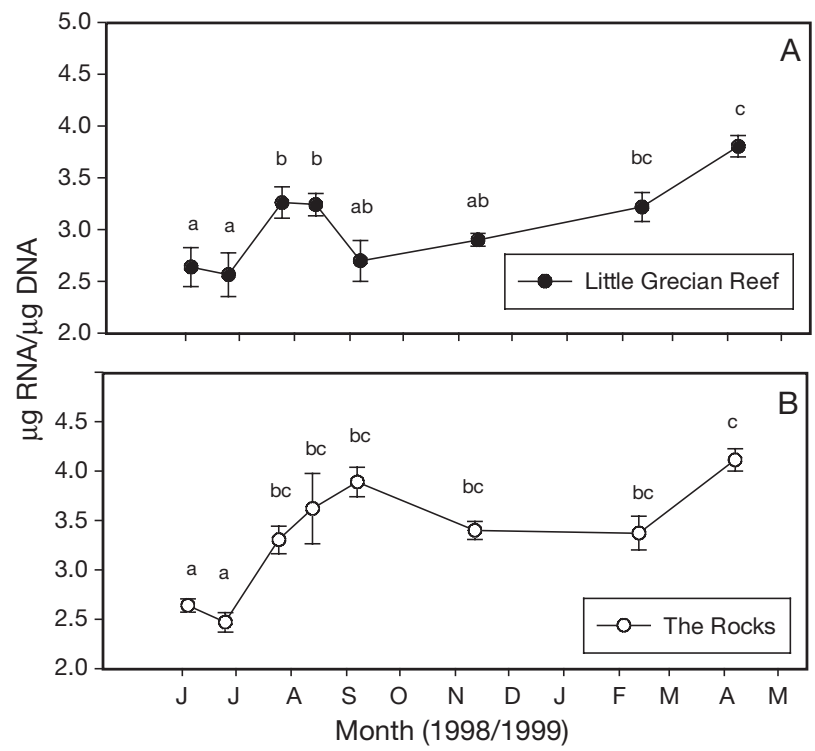

Fig. 4. Montastraea annularis. Seasonal changes in RNA/ DNA ratios (mean $\pm \mathrm{SE}, \mathrm{n}=5$ ) at 2 sites, Little Grecian reef and The Rocks reef. Within each graph, time points labeled with different letters differed significantly from each other $(\mathrm{p}<0.05$, post hoc Tukey test)

\section{Interspecific variation in RNA/DNA ratios}

The RNA/DNA ratio measurements from 3 species of coral, Montastraea annularis, M. cavernosa and M. faveolata, demonstrated that significant interspecific variation exists in this index (Fig. 5). RNA/DNA ratios in $M$. cavernosa were significantly higher than in the other species ( $\mathrm{p}<0.0001$, ANOVA), being approximately $1.7 \times$ greater than in $M$. annularis and $2.4 \times$ greater than in $M$. faveolata. The ratio in $M$. annularis was greater than in $M$. faveolata $(\mathrm{p}=0.006)$.

\section{DISCUSSION}

We investigated the effect of depth, site, season and species on the RNA/DNA ratio in several species of scleractinian corals in an effort to expand our understanding of the use of this index as a tool for assessing coral health in the face of the climate changes predicted by current models (IPCC 2001). To acclimatize to short-term environmental changes, evolutionary improvement in stress resistance and tolerance will be of little value, and to survive individual corals will have to rely on those processes that now allow them to adapt to the annual and seasonal fluctuations routinely experienced in the dynamic tropical ecosystems in which they thrive. Furthermore, management of these ecosystems can be improved by comparative indices of

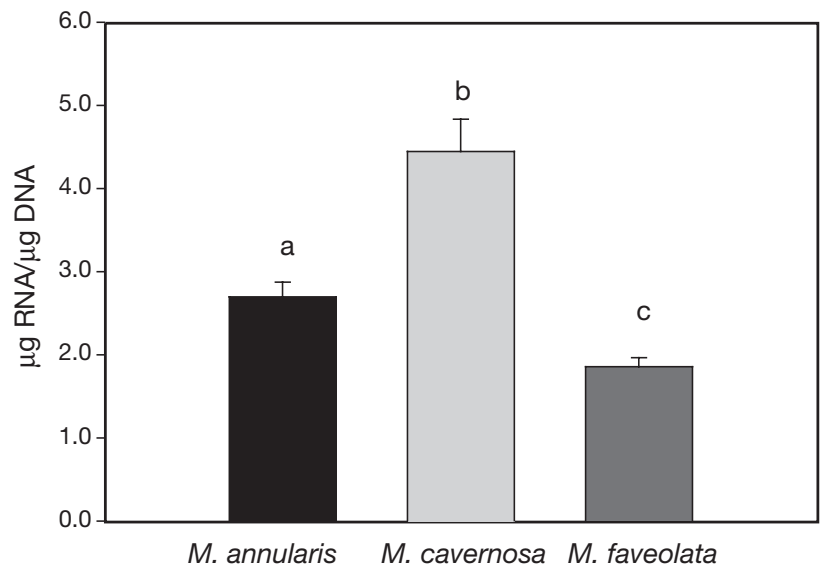

Fig. 5. Montastraea annularis, M. cavernosa, M. faveolata. RNA/DNA ratios (mean + SEM; $\mathrm{n}=5$ ) for individuals of each species collected at Little Grecian reef in September 1998. Ratios labeled with different letters differed significantly from each other ( $p<0.05$, post hoc Tukey test)

coral health, such as that examined here, the RNA/ DNA ratio.

The utility of the RNA/DNA ratio depends upon the assumption that DNA content of somatic cells remains fixed, but that RNA content varies widely with the demand of the cell for protein synthesis. Although the transcriptome does not directly predict the proteome (Gygi et al. 1999), a high RNA/DNA ratio does represent an increased investment in the potential for protein synthesis. While increased protein synthesis might in some cases reflect a stress response, high ratios are usually interpreted as being beneficial, reflecting active metabolic states and elevated protein production for growth and reproduction; thus, higher ratios are expected during periods when, or at locations where, conditions are favorable for these processes (Dahlhoff \& Menge 1996, Dahlhoff et al. 2001). Here, in the anemone Aiptasia pallida, a decrease in the RNA/DNA ratio was observed in individuals that had been deprived of the light needed for autotrophic nutrition (Fig. 2); this is the first laboratory test of nutritional limitation on this ratio in symbiotic cnidarians.

In natural populations, corals thrive in high-light environments where solar energy is transduced through their endosymbiotic algae to comprise a portion of the host's metabolism (Chalker et al. 1983, Falkowski et al. 1984, 1990, Barnes \& Chalker 1990); therefore depth constitutes a primary ecophysiological gradient for these organisms (McCloskey \& Muscatine 1984). We observed an effect of depth on the RNA/DNA ratio (Fig. 3A); however, the effect was minor. The RNA/DNA ratio decreased between 3 and $10 \mathrm{~m}$, but did not vary significantly between 10 and 
$20 \mathrm{~m}$. Ambient light levels, however, did decrease between 10 and $20 \mathrm{~m}$ and, therefore, light alone explained only $29 \%$ of the variance in the ratio (Fig. 3B). It is possible that differences in heterotrophic feeding with depth may also have impacted the RNA/DNA ratios. For instance, if corals at $20 \mathrm{~m}$ were able to compensate for reduced translocation of zooxanthellate photosynthate by increasing heterotrophy, this could explain the equivalent ratios at 10 and $20 \mathrm{~m}$. In another study, robust depth-dependent decreases in RNA/DNA ratios were measured in members of the Porites lutea/P. lobata complex from Java, Indonesia (Meesters et al. 2002).

As factors affecting coral growth vary with season, we postulated that this might be reflected in the RNA/ DNA ratio. In the seasonal sampling of Montastraea annularis at both a shallow, inshore site (TR) and a deeper offshore site (LG), RNA/DNA ratios at both reefs were lowest in June 1998 (Fig. 4), when high water temperatures may have had effects on coral and zooxanthellate metabolism, and were highest in the following winter and spring when lower temperatures may have been closer to optimal for coral growth (Highsmith 1979, Hudson 1981). Seasonal differences in the RNA/DNA ratio in natural populations have also been measured in other marine invertebrates, including the mussel Mytilus californianus and the whelk Nucella ostrina, with higher ratios being observed during seasonal upshifts in food availability (Dahlhoff \& Menge 1996, Dahlhoff et al. 2001).

RNA/DNA ratios at the 2 sites showed divergent patterns in late summer; the ratio at TR continued to rise through August and September, while the ratio at LG decreased (Fig. 4). This disparity could not be explained by differences in water-soluble nutrient availability, as water sampling demonstrated that levels of nitrate, ammonia and phosphate were nearly identical at the 2 sites (A.M.S. unpubl. data), although heterotrophic feeding rates may have varied based on differences in prey availability.

Certainly, differences between autotrophic feeding rates (zooxanthellate photosynthetic activity) at the 2 sites may have played a role in the observed divergence in the RNA/DNA ratios from August and September, as the corals at the 2 sites visibly bleached at different times during the sampling. Temperatures at LG were approximately 2 to $3^{\circ} \mathrm{C}$ lower than at the shallower TR throughout June and early July (data not shown). At TR, the corals bleached soon after we started the sampling for this study and then began to recover, while RNA/DNA ratios steadily increased (Fig. 4B). This may mean that the bleaching event did not hinder normal protein synthesis in Monatsraea annularis and that growth continued uninterrupted. At LG, the onset of bleaching was later and much more acute, occurring over a $2 \mathrm{wk}$ period in late July, and RNA/DNA ratios decreased sharply during this period as well (Fig. 4A). It is possible that the earlier bleaching event at TR allowed the corals to acclimatize through an increase in protein synthesis, perhaps supported by an increase in heterotrophic feeding, while the bleaching event at LG was so acute that the corals were unable to respond as effectively.

In an interspecific comparison, RNA/DNA ratios were higher in Montastraea cavernosa collected at LG in June, 1998 than in M. annularis or M. faveolata (Fig. 5). Interspecific variability in the ratios from the 3 congeners was greater than the range of intraspecific variability observed in the seasonal sampling of M. annularis (ratios ranged between $\sim 2.5$ and 4.0 for seasonal samples and between $\sim 1.9$ and 4.5 for the interspecific study). Therefore, in some comparisons among congeners from different sites, phylogenetic differences may overwhelm the signal from environmentaly driven variation in the RNA/DNA ratio. Gates \& Edmunds (1999) reported a 5-fold intraspecific variation in the RNA/DNA ratio in clones of the coral Madracis mirabilis, although they presented no data. Meesters et al. (2002) measured 2-fold differences in Porites; however these data may have been generated from 1 of 2 species, or possibly a mixture of both. At this time, whether the scale of intra- and interspecific variation measured in this study is generally representative remains to be determined.

In summary, the RNA/DNA ratio was responsive to nutritional manipulation in the laboratory in a symbiotic cnidarian, and showed depth-, site-, season- and species-specific variation in natural populations of several species of Caribbean reef-building corals. These findings support the use of this index as a biomarker of coral metabolic state in natural populations and demonstrate the impact that organismal responses to stress, such as bleaching, can have on protein synthetic capacity. In future studies on the ecophysiology of corals, measurements of the RNA/DNA ratio should be complemented by indices of protein damage and degradation (such as formation of ubiquitin conjugates) and estimates of protein synthesis rates such as those provided by measuring incorporation of ${ }^{14} \mathrm{C}$-alanine into newly synthesized polypeptides, with the goal of achieving a more comprehensive description of protein metabolism in corals experiencing environmental change.

Acknowledgements. We are grateful to I. Baums, J. Borger, R. Carter and K. Cohen for assistance in the field. Our thanks are due to C. Downs and 4 anonymous reviewers for their evaluation of the manuscript. This research was funded through a grant from NOAA-COP to A.M.S. and a University Fellowship from the University of Miami to B.A.B. 


\section{LITERATURE CITED}

Bak RPM, Meesters EH (2002) Acclimatization/adaptation of coral reefs in a marginal environment. Proc 9th Int Coral Reef Symp 1:265-272

Barnes DJ, Chalker BE (1990) Calcification and photosynthesis in reef-building corals and algae. In: Dubinsky Z (ed) Ecosystems of the world: coral reefs, Vol 25. Elsevier, New York, p 109-131

Bentle LA, Dutta SR, Metcoff J (1981) The sequential enzymatic determination of DNA and RNA. Anal Biochem 116: $5-16$

Black NA, Voellmy R, Szmant AM (1995) Heat shock protein production in Montastraea faveolata and Aiptasia pallida exposed to elevated temperatures. Biol Bull (Woods Hole) 188:234-240

Brown BE (1997) Adaptations of reef corals to physical environmental stress. Adv Mar Biol 31:221-298

Buckley L (1984) RNA/DNA ratio: an index of larval fish growth in the sea. Mar Biol 80:291-298

Buckley L, Caldarone E, Ong TL (1999) RNA-DNA ratio and other nucleic acid-based indicators for growth and condition of marine fishes. Hydrobiologia 401:265-277

Bulow FJ (1987) RNA-DNA ratios as indicators of growth in fish: a review. In: Summerfelt RC, Hall GC (eds) The age and growth of fish. Iowa State University Press, Ames, p 45-65

Chalker BE, Dunlap WC, Oliver JK (1983) Bathymetric adaptations of reef-building corals at Davies Reef, Great Barrier Reef, Australia. II. Light saturation curves for photosynthesis and respiration. J Exp Mar Biol Ecol 73: $37-56$

Chícaro LMZ, Chícaro MA, Alves F, Amaral A, Pereira A, Regala J (2001) Diel variation of the RNA/DNA ratios in Crassostrea angulata (Lamarck) and Ruditapes decussates (Linnaeus 1758) (Mollusca: Bivalvia). J Exp Mar Biol Ecol 259:121-129

Dahlhoff EP, Menge BA (1996) Influence of phytoplankton concentration and wave exposure on the ecophysiology of Mytilus californianus. Mar Ecol Prog Ser 14:97-107

Dahlhoff EP, Buckley BA, Menge BA (2001) Physiology of the rocky intertidal predator Nucella ostrina along an environmental stress gradient. Ecology 82:2816-2829

Downs CA, Mueller E, Philips S, Fauth JE, Woodley CM (2000) A molecular biomarker system for assessing the health of coral (Montastraea faveolata) during heat stress. Mar Biotechnol 2:533-544

Downs CA, Fauth JE, Halas JC, Dustan P, Bemiss J, Woodley CM (2002) Oxidative stress and seasonal coral bleaching. Free Radic Biol Med 33:533-543

Edmunds PJ, Gates RD (2003) Normalizing physiological data for scleractinian corals. Coral Reefs 21:193-197

Falkowski PG, Dubinsky Z, Muscatine L, Porter JW (1984) Light and the bioenergetics of a symbiotic coral. BioScience 34:705-709

Falkowski PG, Jokiel PL, Kinzie RA (1990) Irradiance and corals. In: Dubinsky Z (ed) Ecosystems of the world: coral reefs, Vol 25. Elsevier, New York, p 89-107

Frantzis A, Gremare A, Vetion G (1992) Growth rates and RNA/DNA ratios in Paracentrotus lividus (Echinodermata: Echinoidea) fed on benthic macrophytes. J Exp Mar Biol Ecol 156:125-138

Editorial responsibility: Otto Kinne (Editor), Oldendorf/Luhe, Germany
Gardner TA, Côté IM, Gill JA, Grant A, Watkinson AR (2003) Long-term region-wide declines in Caribbean corals. Science 301:958-960

Gates RD, Edmunds PJ (1999) The physiological mechanisms of acclimatization in tropical reef corals. Am Zool 39:30-43

Glynn PW (1993) Coral reef bleaching: ecological perspectives. Coral Reefs 12:1-17

Gwak WS, Tsusaki T, Tanaka M (2003) Nutritional condition, as evaluated by RNA/DNA ratios, of hatchery-reared Japanese flounder from hatch to release. Aquaculture 219: 503-514

Gygi SP, Rochon Y, Franza BR, Aebersold R (1999) Correlation between protein and mRNA abundance in yeast. Mol Cell Biol 19:1720-1730

Hayes RL, King CM (1995) Induction of $70-\mathrm{kD}$ heat shock protein in scleractinian corals by elevated temperature: significance for coral bleaching. Mol Mar Biol Biotechnol $4: 36-42$

Helmuth B, Harley CDG, Halpin PM, O'Donnell M, Hofmann GE, Blanchette CA (2002) Climate change and latitudinal patterns of intertidal thermal stress. Science 298: 1015-1017

Highsmith RC (1979) Coral growth rates and environmental control of density banding. J Exp Mar Biol Ecol 37:105-125

Hoegh-Guldberg O (1999) Climate change, coral bleaching and the future of the world's coral reefs. Mar Freshw Res 50:839-866

Hudson JH (1981) Growth rates in Montastraea annularis: a record of environmental change in Key Largo Coral Reef Marine Sanctuary, Florida. Bull Mar Sci 31:444-459

Hughes TP, Baird, AH, Bellwood DR, Card M and 13 others (2003) Climate change, human impacts and the resilience of coral reefs. Science 301:929-933

IPCC (2001) Climate change 2001: impacts, adaptation and vulnerability. Contribution of Working Group II to the Intergovernmental Panel on Climate Change, Third Assessment Report. Cambridge University Press, Cambridge

Malloy KD, Targett TE (1994) The use of RNA:DNA ratios to predict growth limitation of juvenile summer flounder (Paralichthys denatus) from Delaware and North Carolina estuaries. Mar Biol 118:367-375

McCloskey LR, Muscatine L (1984) Production and respiration in the Red Sea coral Stylophora pistillata as a function of depth. Proc R Soc Lond Ser B 222:215-230

McNamara PT, Caldarone EM, Buckley LJ (1999) RNA/DNA ratio and expression of $18 \mathrm{~S}$ ribosomal RNA, actin and myosin heavy chain messenger RNAs in starved and fed larval Atlantic cod (Gadus morhua). Mar Biol 135:123-132

Meesters EH, Nieuwland G, Duineveld GCA, Kok A, Bak RPM (2002) RNA/DNA ratios of scleractinian corals suggest acclimatization/adaptation in relation to light gradients and turbidity regimes. Mar Ecol Prog Ser 227:233-239

Shick JM, Lesser MP, Dunlap WC, Stochaj WR, Chalker BE, Won JW (1995) Depth-dependent responses to solar ultraviolet radiation and oxidative stress in the zooxanthellate coral Acropora microphthalma. Mar Biol 122:41-51

Wilkinson CR (1996) Global change and coral reefs: impacts on reefs, economies and human cultures. Glob Change Biol 2:547-558

Wright DA, Hetzel EW (1985) Use of RNA:DNA ratios as an indicator of nutritional stress in the American oyster Crassostrea virginica. Mar Ecol Prog Ser 25:199-206

Submitted: February 6, 2004; Accepted: July 22, 2004

Proofs received from author(s): October 26, 2004 